\title{
Anestesia em Paciente com Xeroderma Pigmentoso. Relato de Caso *
}

\author{
Anesthesia in Patient with Xeroderma Pigmentosum. Case Report
}

\author{
Carlos Rogério Degrandi Oliveira ${ }^{1}$, Luciana Elias ${ }^{1}$, Ana Cláudia de Melo Barros ${ }^{2}$, Diogo Brüggemann da Conceição ${ }^{3}$
}

\section{RESUMO}

Oliveira CRD, Elias L, Barros ACM, Conceição DB - Anestesia em Paciente com Xeroderma Pigmentoso. Relato de Caso

Justificativa e Objetivos - O Xeroderma Pigmentoso é uma doença autossômica recessiva rara, caracterizada pelo desenvolvimento prematuro de neoplasias devido à extrema sensibilidade à radiação ultravioleta. Estas manifestações ocorrem por falha no mecanismo de excisão e reparo do DNA. Se comparados a indivíduos normais, estes pacientes apresentam risco 1000 vezes maior de desenvolver neoplasias em áreas expostas ao sol. O objetivo deste relato é apresentar a conduta anestésica em uma paciente portadora de Xeroderma Pigmentoso submetida à cirurgia oftalmológica.

Relato do Caso - Paciente do sexo feminino, 7 anos, portadora de Xeroderma Pigmentoso com comprometimento facial extenso, admitida para exérese de lesão papilar no olho direito. Foi prescrito midazolam (10 mg) por via oral, como medicação pré-anestésica. A monitorização inicial consistiu de cardioscópio, oxímetro de pulso, estetoscópio precordial e pressão arterial não invasiva. Foi realizada pré-oxigenação com oxigênio a $100 \%$ por 3 minutos e indução inalatória sob máscara com oxigênio a $100 \%$ e sevoflurano em concentrações crescentes até 7\%. Após acesso venoso periférico com cateter $22 \mathrm{G}$, foram injetados propofol $(50 \mathrm{mg})$ e succinilcolina $(20 \mathrm{mg}$ ) e realizada intubação traqueal com tubo $5,5 \mathrm{~mm}$ sem balonete. Um guia de metal foi utilizado para facilitar a introdução do tubo traqueal. A manutenção da anestesia foi feita com sevoflurano a 3,5\% e oxigênio a 100\%, com sistema de Bain. A criança foi extubada na sala cirúrgica e encaminhada à sala de recuperação pós-anestésica em boas condições.

Conclusões - As alterações faciais e orofaríngeas decorrentes desta doença determinaram dificuldades na adaptação da máscara facial e intubação traqueal. A educação constante do paciente e de seus familiares constitui o objetivo mais importante no manuseio desta doença.

UNITERMOS - ANESTESIA, Pediátrica; DOENÇAS: xeroderma pigmentoso

\footnotetext{
* Recebido do (Received from) Hospital Universitário da Universidade Federal de Santa Catarina, Florianópolis, SC.

1. Anestesiologista do Hospital Universitário - UFSC

2. $M E_{1}$ do CET/SBA Integrado do SES-SC

3. $M E_{2}$ do CET/SBA Integrado do SES-SC
}

Apresentado (Submitted) em 11 de abril de 2002

Aceito (Accepted) para publicação em 07 de junho de 2002

Correspondência para (Mail to):

Dr. Carlos Rogério Degrandi Oliveira

Rua Capitão Américo, 71/501

88037-060 Florianópolis, SC

E-mail: degrandi@bol.com.br

(c) Sociedade Brasileira de Anestesiologia, 2003

\section{SUMMARY}

Oliveira CRD, Elias L, Barros ACM, Conceição DB - Anesthesia in Patient with Xeroderma Pigmentosum. Case Report

Background and Objectives - Xeroderma Pigmentosum is a rare, autosomal recessive disease characterized by the premature development of neoplasias due to an exacerbated hypersensitivity to UV radiation. These manifestations are due to DNA excision and repair mechanism damage. As compared to normal individuals, these patients have a 1000-fold increased risk for developing neoplasias on sun-exposed areas. This report aimed at describing the anesthetic management of a patient with Xeroderma Pigmentosum submitted to ophthalmologic surgery.

Case Report - Female patient, 7 years of age, with Xeroderma Pigmentosum and extensive facial involvement, submitted to right eye papillomatous lesion excision. Patient was premedicated with $10 \mathrm{mg}$ oral midazolam. Initial monitoring consisted of cardioscope, pulse oximetry, precordial stethoscope and noninvasive blood pressure. Patient was preoxygenated with $100 \%$ oxygen for 3 minutes and inhalational anesthesia was induced with sevoflurane under mask in incremental concentrations up to $7 \%$. Peripheral venous access was achieved with a $22 \mathrm{G}$ catheter followed by intravenous $50 \mathrm{mg}$ propofol and $20 \mathrm{mg}$ succinylcholine and tracheal intubation with a $5.5 \mathrm{~mm}$ uncuffed tracheal tube. A guide wire was used to help tracheal tube introduction. Anesthesia was maintained with $3,5 \%$ sevoflurane and $100 \%$ oxygen with Bain's Circuit. Patient was extubated in the operating room and was sent to the post-anesthetic care unit in good conditions.

Conclusions - Facial and oropharyngeal changes caused by this pathology have imposed many difficulties for facial mask adaptation and tracheal intubation. Patient and relatives continuous education are the most important Xeroderma Pigmentosum management objective.

KEY WORDS: ANESTHESIA, Pediatric; DISEASES: xeroderma pigmentosum

\section{INTRODUÇÃO}

$\mathrm{O}$ Xeroderma Pigmentoso é uma doença autossômica recessiva rara, na qual o paciente apresenta extrema sensibilidade a radiação ultravioleta, devido à falha no mecanismo de excisão e reparo do DNA ${ }^{1,2}$. Descrita inicialmente por Kaposi em 1870, inicia-se na infância e progride determinando lesões pré-malignas e malignas que geralmente levam os indivíduos acometidos ao óbito no início da vida adulta ${ }^{3}$. Foram identificados oito subtipos (XP-A a $X P-G$ e XP-V), relacionados à heterogeneidade genética da doença, que se caracteriza principalmente por manifestações dermatológicas, tais como, atrofia, queratose, telangectasias, hiperpigmentação e neoplasias em áreas expostas à luz solar. Há, nesses casos, um risco 1000 ve- 
zes maior de desenvolvimento de neoplasias cutâneas se comparados com a população geral, sendo os tipos histológicos mais freqüentes o carcinoma basocelular e o espinocelular $^{1,2}$. Cerca de $5 \%$ dos casos desenvolvem melanoma, sendo a face e o pescoço as localizações mais freqüentes ${ }^{4}$. A principal causa de óbito destes pacientes são as metástases, sendo que somente $40 \%$ chegam à vida adulta. Dentre as alterações oculares, a fotofobia costuma ocorrer antes das lesões cutâneas, seguidas por catarata bilateral e maior risco de tumores oculares benignos e malignos ${ }^{5}$. Como alterações neurológicas, pode-se citar retardo mental, síndrome piramidal e neuropatia periférica ${ }^{6}$. Quando a doença é acompanhada de alterações neurológicas, hipogonadismo e atraso do desenvolvimento pôndero-estrutural, constitui-se a Síndrome de De Sanctis Cacchione, na qual a capacidade de reparo do DNA pode estar reduzida em até $7,5 \%$, em relação a $100 \%$ no grupo controle ${ }^{7,8}$.

Ocorre em cerca de 1:250.000 nascimentos nos Estados Unidos e 1:40.000 no Japão, podendo tornar-se freqüente em grupos raciais em que existe consangüinidade ${ }^{9}$.

Ocorre com pouca freqüência na raça negra ${ }^{10}$. Geralmente, é diagnosticada entre 1 e 2 anos de idade, porém a intensidade e precocidade dos sinais e sintomas dependem do gene envolvido. Os subtipos A, C , D e G estão relacionados a uma maior gravidade da doença. Não existe diferença de incidência entre os sexos ${ }^{4}$. O diagnóstico é essencialmente clínico, mas existem estudos realizados em laboratórios especializados que podem confirmar o diagnóstico, mesmo antes do nascimento através de amniocentese ${ }^{11}$.

O objetivo deste relato é mostrar a conduta anestésica e os cuidados per-operatórios em paciente com Xeroderma Pigmentoso com acometimento facial extenso, submetida à cirurgia oftalmológica no olho direito para exérese de lesão papilar que se desenvolvia próximo à pupila.

\section{RELATO DO CASO}

Paciente com 7 anos, sexo feminino, branca, $21 \mathrm{~kg}$, com desenvolvimento neuromotor e psíquico normal, com diagnóstico de Xeroderma Pigmentoso desde os 2 anos de idade. Foi admitida para exérese de lesão ocular à direita. Na história familiar, destacam-se dois casos semelhantes no lado paterno, falecidos aos 11 e 16 anos. Esteve internada há 1 ano para exérese de lesões na face. Naquela ocasião, a opção cirúrgica encontrada foi à excisão das lesões maiores respeitando as unidades estéticas da face, utilizando, para tal, enxerto de pele parcial da coxa ${ }^{12}$. Foi realizada também tarsorrafia temporária no olho esquerdo. Evoluiu, no $4^{\circ}$ dia de pós-operatório, com perda da enxertia por infecção de uma grande área na face. Optou-se por aguardar a cicatrização por segunda intenção. Posteriormente foi realizada uma segunda intervenção com o objetivo de excisar novas lesões e de liberar a tarsorrafia do olho esquerdo, que não foi possível devido à proximidade de uma área do tumor residual com o globo ocular esquerdo, mantendo-se assim sua oclusão. As áreas tumorais remanescentes foram tratadas por eletrodissecção. Na reavaliação do $3^{\circ}$ mês de pós-operatório, a paciente apresentava um "congelamento" da mímica facial, ectrópio à direita e retração do lábio superior. Novos tumores eram evidentes.

Na visita pré-anestésica da atual cirurgia, a paciente encontrava-se, com sua mãe, em isolamento respiratório em um ambiente com pouca iluminação. Ao exame físico, apresentava ectrópio à direita, opacificação da conjuntiva direita com lesão próxima à pupila, retração do lábio superior, intensa sialorréia, retrognatismo e limitação da abertura da boca com Mallampati classe III. Notava-se ainda, poiquilodermia acentuada com ceratose actínica em todo o corpo, mas principalmente nas áreas expostas à radiação ultravioleta. Apresentava radiografia de seios da face com opacificação de seios maxilares e células etmoidais. Cintilografia do esqueleto, ecografia abdominal total e tomografia computadorizada do crânio não mostraram anormalidades. Nos exames laboratoriais, constava discreta leucocitose e aumento de VHS. Demais exames pré-operatórios sem alterações. Fazia uso de isotretinoína (10 mg), por via oral, cada 24 horas e 5-fluorouracil $(250 \mathrm{mg})$, por via venosa, cada 7 dias.

Como medicação pré-anestésica, foi utilizado midazolam em solução oral ( $10 \mathrm{mg}$ ), 30 minutos antes do procedimento, o que a deixou tranqüila e cooperativa. A paciente foi recebida na sala cirúrgica sem acesso venoso, sendo monitorizada com oxímetro de pulso, cardioscópio, estetoscópio precordial, aparelho de pressão arterial não-invasiva e, posteriormente, capnógrafo. Devido às experiências anteriores, a própria paciente pediu para segurar a máscara sobre a face no início da indução (Figura1).

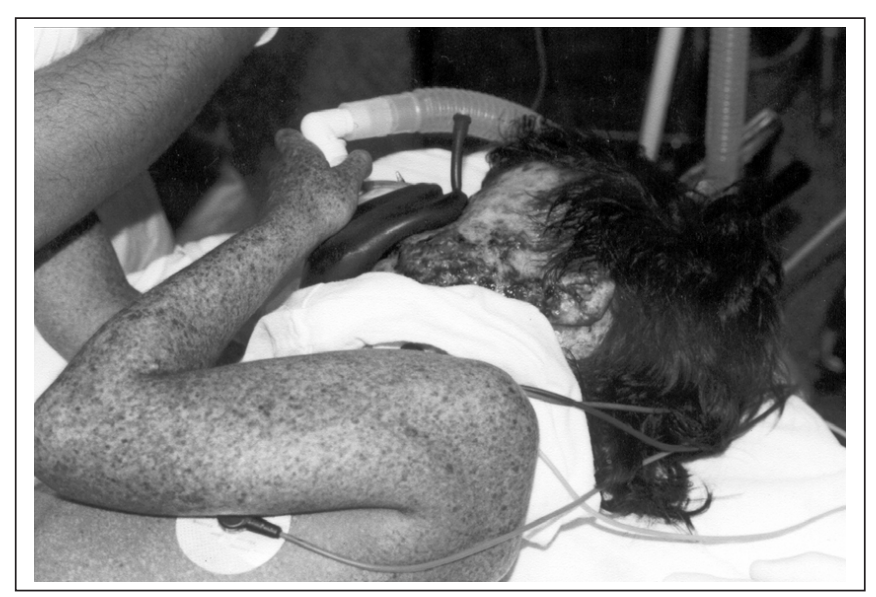

Figura 1 - Paciente Leva a Máscara à Face

A técnica anestésica adotada foi indução inalatória sob máscara com oxigênio a $100 \%$ e sevoflurano em concentrações crescentes até $7 \%$. Devido às alterações dermatológicas citadas anteriormente houve dificuldade para se obter acesso venoso. Foi realizada venóclise na fossa cubital esquerda com cateter venoso $22 \mathrm{G}$ e administrados propofol (50 mg) e succinilcolina (20 mg). A seguir foi feita laringoscopia direta, não sendo possível a visualização da glote, optando-se por interromper a laringoscopia e ventilar a paciente. Uma se- 
gunda tentativa de intubação foi realizada com tubo $n^{\circ} 5,5$ $\mathrm{mm}$ sem balonete, com auxílio de guia metálico, com sucesso (Figuras 2 e 3). Em virtude das inúmeras lesões na face e orofaringe, houve dificuldade na adaptação da máscara, e na intubação traqueal. A manutenção da anestesia foi feita com sevoflurano a $3,5 \%$ e oxigênio a $100 \%$, com sistema de Bain, sem intercorrências. Como analgesia foram utilizados $450 \mathrm{mg}$ de dipirona, por via venosa. Ao término do procedimento foi encaminhada à sala de recuperação pós-anestésica, onde sua mãe a aguardava. Permaneceu hospitalizada a fim de completar esquema quimioterápico. Posteriormente, o laudo anatomopatológico revelou que a lesão tratava-se de um carcinoma espinocelular.

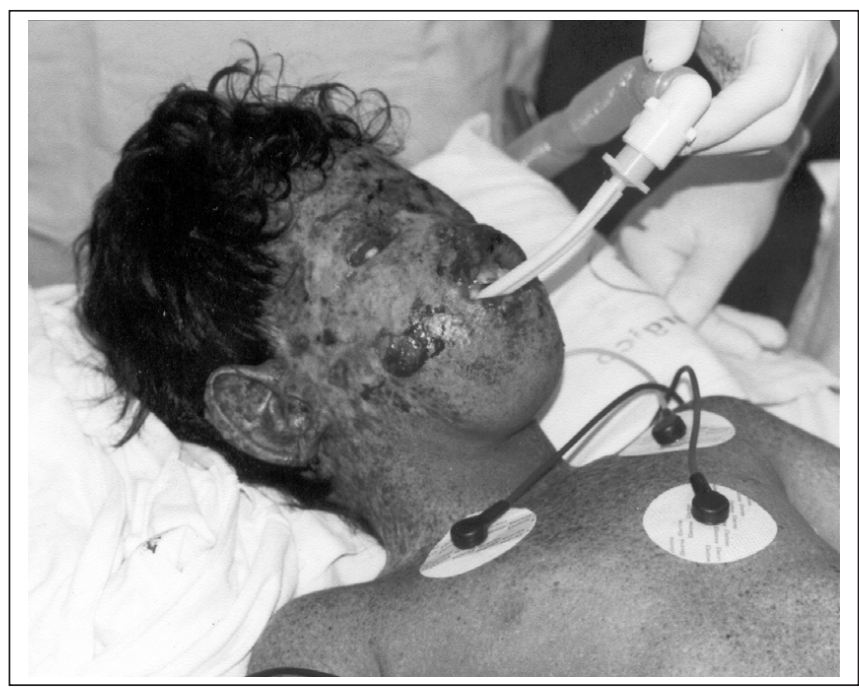

Figura 2 - Hemiface Direita

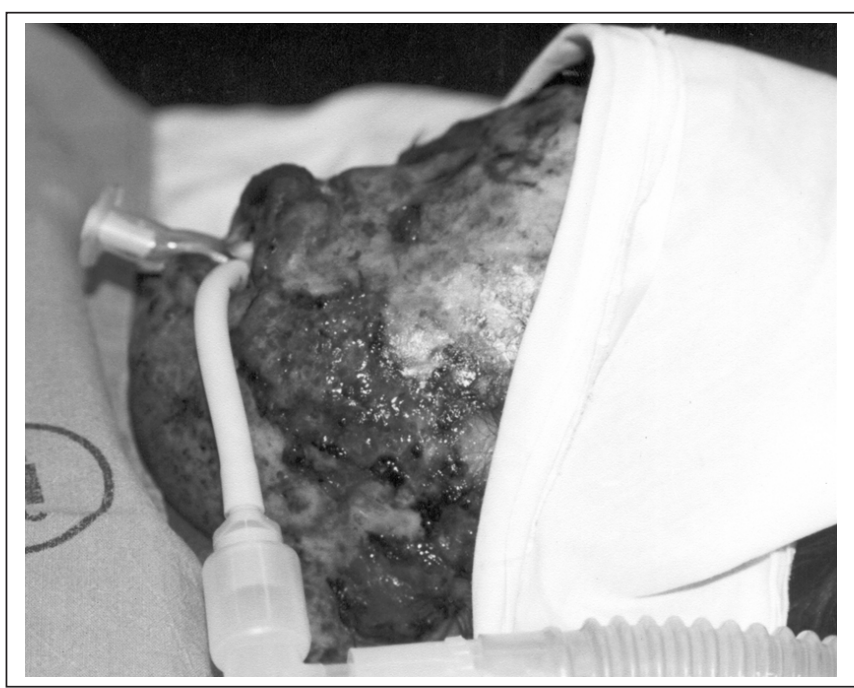

Figura 3 - Paciente Preparada para o Procedimento. Hemiface Esquerda

\section{DISCUSSÃO}

As alterações decorrentes do Xeroderma Pigmentoso, doença primariamente dermatológica, impuseram vários desafios ao ato anestésico. Isso ocorreu principalmente pelas múltiplas lesões faciais que a paciente apresentava, prejudicando a adaptação da máscara a sua face. A presença de microstomia e lesões na cavidade orofaríngea dificultaram a intubação traqueal.

A opção pelo sevoflurano, como agente inalatório, baseou-se nas suas propriedades favoráveis para anestesia pediátrica, bem como para procedimentos de curta duração ${ }^{13}$. Há relato na literatura de que o enflurano deve ser evitado em pacientes com Xeroderma Pigmentoso, pois poderá induzir alterações irreversíveis no DNA, piorando o prognóstico desses pacientes ${ }^{14}$. O óxido nitroso também deve ser utilizado com cautela em pacientes usuários de 5-fluorouracil ${ }^{15}$

A educação constante do paciente e de seus familiares constitui o objetivo mais importante no manuseio desta doença. A profilaxia baseia-se principalmente na proteção do paciente contra a luz solar, através do uso de protetores solares, óculos e roupas que impeçam a penetração dos raios ultravioleta $^{16}$. A cirurgia e a eletrocoagulação, assim como o emprego do 5-fluorouracil, dos retinóides e a imunoterapia são algumas opções de tratamento disponíveis, mas nenhuma delas é completamente eficaz, além da ocorrência dos diversos efeitos colaterais, devendo-se, portanto, considerar os benefícios do seu uso ${ }^{17-20}$. A excisão completa dos tumores malignos deve ser realizada sempre. A radioterapia como tratamento paliativo para as lesões malignas deverá ser utilizada com cautela, visto que os efeitos colaterais das radiações ionizantes poderão influenciar a expectativa de vida destes pacientes ${ }^{21,22}$.

Tão importante quanto o aspecto anestésico-cirúrgico que a doença acarreta, uma vez que esse tipo de paciente necessita de intervenções cirúrgicas freqüentes, é o impacto psicossocial imposto ao paciente e a seus familiares. A progressão da doença traz uma série de limitações às atividades diárias da criança e exige de seus pais um grau de atenção e de cuidados muito grande. Assim, torna-se de fundamental importância a visita pré-anestésica atenciosa, bem como a correta indicação da medicação pré-anestésica, visando diminuir a ansiedade e o estresse emocional por que passam esses pacientes.

Essa doença é um exemplo de como algumas doenças dermatológicas podem vir a afetar de maneira tão significativa o ato anestésico-cirúrgico, pois, nessa criança, encontraram-se dificuldades para a venóclise, para a indução inalatória por máscara, para intubação traqueal e, por fim, até mesmo para a excisão das lesões faciais. 


\section{Anesthesia in Patient with Xeroderma Pigmentosum. Case Report}

Carlos Rogério Degrandi Oliveira, M.D., Luciana Elias, M.D., Ana Cláudia de Melo Barros, M.D., Diogo Brüggemann da Conceição, M.D.

\section{INTRODUCTION}

Xeroderma pigmentosum is a rare autosomal recessive disease in which patients are extremely sensitive to UV radiation due to DNA excision and repair mechanism changes ${ }^{1,2}$. Initially described by Kaposi in 1870, it starts during childhood and progresses to determine pre-malignant and malignant injuries which in general lead affected individuals to death in early adult life ${ }^{3}$. Eight sub-types were identified (XP-A to $X P-G$ and $X P-V$ ) and related to genetic disease heterogeneity, mainly characterized by dermatological manifestations such as atrophy, keratosis, telangiectasis, hyperpigmentation and neoplasias in areas exposed to sunlight. In those cases, there is a 1000 -fold increased risk for developing skin neoplasias, as compared to normal individuals, being basal cell and squamous cell carcinomas the most common histological types ${ }^{1,2}$. Approximately $5 \%$ of cases develop melanoma and face and neck are the most common sites $^{4}$. Major causes of deaths are metastasis and only $40 \%$ of patients reach adult life. Among ocular changes, photophobia may be present before skin lesions and is followed by bilateral cataract and a higher risk for benign and malignant eye tumors ${ }^{5}$. Among neurological changes one might mention mental retardation, pyramidal syndrome and peripheral neuropathy ${ }^{6}$. When the disease is followed by neurological changes, hypogonadism and height-weight development delay it characterizes the De Sanctis Syndrome, in which DNA repair ability may be decreased up to $7.5 \%$ as compared to $100 \%$ in normal individuals ${ }^{7,8}$.

The incidence of Xeroderma Pigmentosum is $1: 250,000$ births in the USA and 1:40,000 in Japan and may be frequent in racial groups where there is consanguinity ${ }^{9}$.

It is rare among blacks ${ }^{10}$ and is generally diagnosed between 1 and 2 years of age. Signs and symptoms intensity and precocity, however, depend on the involved gene. Subtypes A, $C, D$ and $G$ are related to more severe disease. There is no difference in incidence between genders ${ }^{4}$. The diagnostic is essentially clinic, but there are amniocentesis studies performed by specialized labs which may confirm the diagnosis even before birth ${ }^{11}$.

This report aimed at describing the anesthetic approach and perioperative care of a xeroderma pigmentosum patient with extensive facial involvement and submitted to right eye surgery to excise a papillomatous lesion close to the pupil.

\section{CASE REPORT}

Caucasian female patient, 7 years of age, $21 \mathrm{~kg}$, normal neuromotor and psychic development with xeroderma pigmentosum diagnosed at 2 years of age and admitted to right ocular lesion excision. Family history showed two similar cases on the paternal side, who died at 11 and 16 years of age. Patient had been hospitalized one year ago for facial lesions excision. By that time, the surgical option was to excise major lesions respecting facial esthetic units and using partial thigh skin grafting ${ }^{12}$. Temporary left eye tarsorrhaphy was also performed. In the $4^{\text {th }}$ postoperative day, patient evolved with graft rejection by infection of a major area of the face. The option was then to wait healing by second intention. Asecond intervention was performed later with the aim of excising new lesions and release left eye tarsorrhaphy, which was impossible due to a residual tumor area close to the left eyeball and occlusion was maintained. Remaining tumor areas were treated by electrodisection. In the $3^{\text {rd }}$ postoperative month patient presented facial "freezing", right ectropium and upper lip retraction. New tumors were evident.

In the preanesthetic evaluation for this surgery patient was, with her mother, in respiratory isolation in a poorly lit environment. At physical evaluation she presented right ectropium, right conjuntiva opacification with a lesion close to the pupil, upper lip retraction, major sialorrhea, retrognathism and mouth opening limitation with Mallampati class III. There was also marked poikiloderma with actinic keratosis throughout the body, but especially in areas exposed to UV radiation. Facial sinus X-ray showed maxillary sinuses opacification and ethmoidal cells. Skeletal scintigraphy, total abdominal echography and brain CT were normal. Lab tests revealed mild leucocytosis and increased VHS. Other preoperative tests were normal. Patient was under oral isotretinoin (10 $\mathrm{mg}$ ) once a day and intravenous 5-FU (250 mg) once a week. Patient was premedicated with oral midazolam $(10 \mathrm{mg}) 30$ minutes before surgery, what has made her relaxed and cooperative. Patient was admitted to the operating room without venous access and was monitored with pulse oximetry, cardioscopy, precordial stethoscope, noninvasive blood pressure and capnography. Due to previous experiences, the patient asked to hold the facial mask in place during beginning of induction (Figure 1).

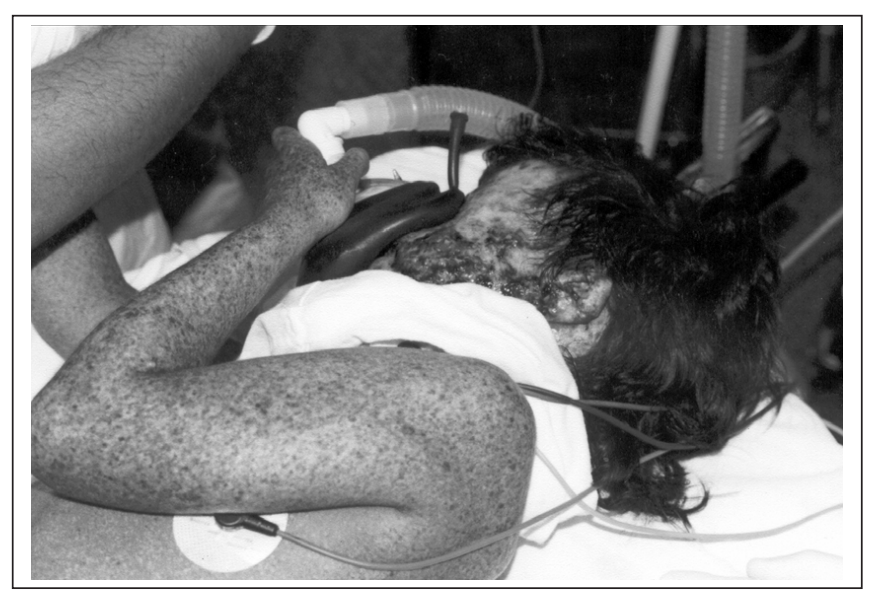

Figure 1 - Patient brings the mask to her face 
Inhalational anesthesia was induced under mask with 100\% oxygen and sevoflurane in incremental concentrations until $7 \%$. Due to the above-mentioned dermatologic problems, venous access was difficult to obtain. Venoclysis was performed at the left cubital fossa with a $22 \mathrm{G}$ venous catheter and propofol $(50 \mathrm{mg})$ and succinylcholine $(20 \mathrm{mg})$ were administered. Then, direct laryngoscopy was performed and it was impossible to see the glottis. The option was to discontinue laryngoscopy and ventilate the patient. A second successful intubation was performed with a $5.5 \mathrm{~mm}$ uncuffed tube and the aid of a guide wire (Figures 2 and 3). Due to several facial and oropharyngeal injuries, it was difficult to adapt the mask and to perform intubation. Anesthesia was maintained with $3.5 \%$ sevoflurane and $100 \%$ oxygen with the Bain's system without intercurrences. Analgesia was induced with intravenous dipirone. At surgery completion, pa-

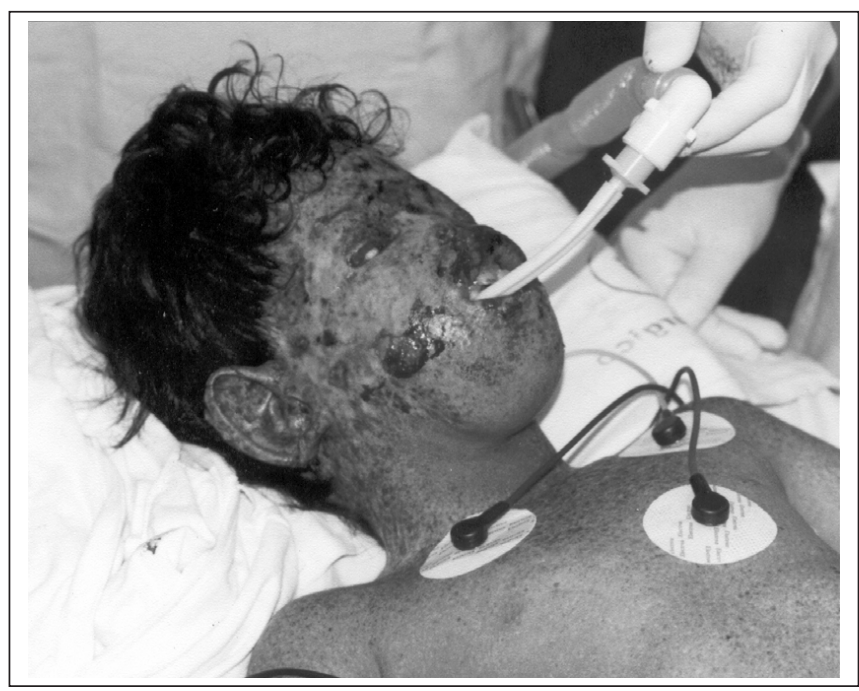

Figure 2 - Right side of the face

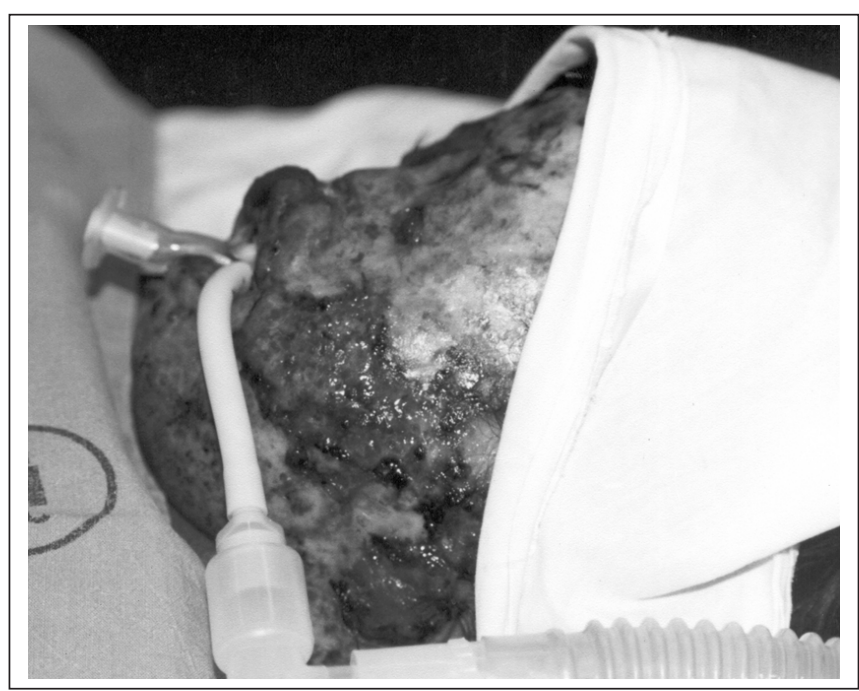

Figure 3 - Patient prepared for the procedure. Left side of the face tient was referred to the post-anesthetic care unit where her mother was waiting for her. Patient remained hospitalized to complete her chemotherapeutic schedule. Pathology revealed a squamous cell carcinoma.

\section{DISCUSSION}

Xeroderma pigmentosum-induced changes, which are primarily dermatologic, have imposed several challenges to anesthetic induction. This was especially due to several facial lesions which impaired facial mask adaptation. Microstomia and oropharyngeal injuries made tracheal intubation difficult.

The decision of using sevoflurane as the inhalational agent was based on its favorable properties for pediatric anesthesia and short procedures ${ }^{13}$. According to a report in the literature, enflurane should be avoided in Xeroderma Pigmentosum patients because it may induce irreversible DNA changes and worsen the prognosis of such patients ${ }^{14}$. Nitrous oxide should also be carefully used in patients under $5-\mathrm{FU}^{15}$. Patients and relatives' continuous education is the most important objective in managing this disease. Prevention is primarily based on protecting patients against sunlight with sun protectors, glasses and clothes preventing UV rays penetration ${ }^{16}$. Surgery and electrocoagulation, in addition to 5-FU, retinoids and immunotherapy are some available options, but none of them is fully effective, and the presence of several side-effects may limit the benefits of such therapies 17-20. Malignant tumors should always be totally excised. Radiation therapy as a palliation treatment for malignant tumors should be carefully used since ionizing radiation side-effects may influence life expectation of such patients ${ }^{21,22}$.

The psychosocial impact imposed to patients and their relatives is as important as the surgical-anesthetic aspect of the disease, since these patients require frequent surgical interventions. The progression of the disease is followed by limitations in children's daily activities and requires a high level of parent's attention and care. So, a careful preanesthetic evaluation and the correct preanesthetic medication are critical to decrease anxiety and the emotional stress these patients are under.

This is an example of how dermatological diseases may so significantly affect surgery and anesthesia because with this child there were difficulties in venoclysis, inhalational anesthesia under mask, tracheal intubation and eventually even in facial lesions excision.

\section{REFERÊNCIAS - REFERENCES}

01. Van Steeg $\mathrm{H}$, Kraemer $\mathrm{KH}$ - Xeroderma Pigmentosum and the role of UV-induced DNA damage in skin cancer. Mol Med Today, 1999;5:86-94.

02. Kraemer KH, Lee MM, Andrews AD et al - The role of sunlight and DNA repair in melanoma and nonmelanoma skin cancer. The Xeroderma Pigmentosum paradigm. Arch Dermatol, 1994;130:1018-1021.

03. Minelli L, Neme LC - Xeroderma Pigmentoso. Rev Bras Med, 1996;53:401-402 
04. Kraemer KH, Lee MM, Scotto J - Xeroderma Pigmentosum. Cutaneous, ocular and neurologic abnormalities in 830 published cases. Arch Dermatol, 1987;123:241-250.

05. Hertle RW, Durso F, Metzler JP et al - Epibulbar squamous cell carcinomas in brothers with Xeroderma Pigmentosum. J Pediatr Ophtalmol Strabismus, 1991;28:350-353.

06. Kanda T, Oda M, Yonezawa M et al - Peripheral neuropathy in Xeroderma Pigmentosum. Brain, 1990;113:1025-1044.

07. Niederauer HH, Rohnert E, Altmeyer $\mathrm{P}$ et al - De Sanctis Cacchione Syndrome: Xeroderma Pigmentosum with oligophrenia, short stature and neurological disorders. Hautarzt, 1992;43:25-27.

08. Marini M - Síndrome de De Sanctis Cacchione. Rev Argent Dermatol, 1993;64:149-154.

09. Hasanoglu A, Gücüyener K, Tümer L et al - Association of Xeroderma Pigmentosum with thrombasthenia. Turk J Pediat, 1996;38:261-264.

10. Moussala M, Behar-Cohen F, D'hermies F et al - Xeroderma Pigmentosum and its ocular manifestations. The first case in Camerum. J Fr Ophtalmol, 2000;23:369-374.

11. Moriwaki S, Kraemer KH - Xeroderma Pigmentosum-bridging a gap between clinic and laboratory. Photodermatol Photoimmunol Photomed, 2001;17:47-54.

12. Pitanguy I, Soares G, Torres ET et al - Xeroderma Pigmentoso: apresentação de um caso clínico. Rev Bras Cir, 1992;82: 217-226.

13. Oliveira CRD, Santos GM, Tanaka VY et al - Sevoflurano como agente único para exames oftalmológicos em pacientes pediátricos, em: Canessa B- Libro Resumenes - XXIV CLASA/ XXV Congreso Chileno de Anestesíologia, Santiago do Chile, Gaete, 1997;239.

14. Reitz M, DasGupta K, Brandt L - Detection of DNA damage in stimulated human lymphocytes after enflurane exposure in vitro. Environ Res, 1992;59:476-484.

15. Lacerda MA - Quimioterapia e anestesia. Rev Bras Anestesiol, 2001;51:250-270.

16. Nalgirkar AR, Borkar SS, Nalgikar AS - Xeroderma Pigmentosum with multiple malignances. Indian Pediatrics, 2000;37:1377-1379.

17. Candiani JO, Siwady GS, Gutierrez LF et al - Dermabrasion in Xeroderma Pigmentosum. Dermatol Surg, 1996;22:575-577.

18. Craven NM, Griffiths CF - Retinoids in the management of non-melanoma skin cancer and melanoma. Cancer Surv, 1996;26:267-288.

19. Saade M, Debahy NE - Clinical remission of Xeroderma Pigmentosum-associated squamous cell carcinoma with isotretinoin and chemotherapy: case report. J Chemother, 1999;11:313-317.
20. Wee SY, Ahn DS - Facial resurfacing in Xeroderma Pigmentosum with chemical peeling. Plast Reconstr Surg 1999;103:1464-1467.

21. Yamashiro S, Nagashiro S, Mimata C et al - Malignant trigeminal schwannoma associated with Xeroderma Pigmentosum. Case report. Neurol Med Chir, 1994;34:817-820.

22. Sakata K, Aoki Y, Kumakura $Y$ et al - Radiation therapy for patients with Xeroderma Pigmentosum. Radiot Med, 1996; $14: 87-90$

\section{RESUMEN}

Oliveira CRD, Elias L, Barros ACM, Conceição DB - Anestesia en Paciente con Xeroderma Pigmentoso. Relato de Caso

Justificativa y Objetivos - El Xeroderma Pigmentoso es una enfermedad autosómica recesiva rara, caracterizada por el desenvolvimiento prematuro de neoplasias debido a la extrema sensibilidad a la radiación ultravioleta. Estas manifestaciones ocurren por falla en el mecanismo de excisión y reparo del DNA. Si comparados a individuos normales, estos pacientes presentan riesgo 1000 veces mayor de desenvolver neoplasias en áreas expuestas al sol. El objetivo de este relato es presentar la conducta anestésica en una paciente portadora de Xeroderma Pigmentoso sometida a cirugía oftalmológica.

Relato del Caso - Paciente del sexo femenino, 7 años, portadora de Xeroderma Pigmentoso con comprometimiento facial extenso, admitida para exéresis de lesión papilar en el ojo derecho. Fue prescrito midazolam $(10 \mathrm{mg})$ por vía oral, como medicación pré-anestésica. La monitorización inicial consistió de cardioscópio, oxímetro de pulso, estetoscopio precordial y presión arterial no invasiva. Fue realizada pré-oxigenación con oxígeno a $100 \%$ por 3 minutos e inducción inhalatoria bajo máscara con oxígeno a $100 \%$ y sevoflurano en concentraciones crecientes hasta 7\%. Después de acceso venoso periférico con catéter $22 \mathrm{G}$, fueron inyectados propofol (50 mg) y succinilcolina $(20 \mathrm{mg})$ y realizada intubación traqueal con tubo $5,5 \mathrm{~mm}$ sin balonete. Un guía de metal fue utilizado para facilitar la introducción del tubo traqueal. La manutención de la anestesia fue hecha con sevoflurano a 3,5\% y oxígeno a $100 \%$, con sistema de Bain. La niña fue extubada en la sala cirúrgica y encaminada a la sala de recuperación pós-anestésica en buenas condiciones.

Conclusiones - Las alteraciones faciales y orofaríngeas decurrentes de esta enfermedad determinaron dificultades en la adaptación de la máscara facial e intubación traqueal. La educación constante del paciente y de sus familiares constituye el objetivo más importante en el manoseo de esta enfermedad. 